\title{
A focus on homocysteine in autism
}

\author{
Joanna Kałużna-Czaplińska ${ }^{凶}$, Ewa Żurawicz, Monika Michalska and Jacek Rynkowski \\ Institute of General and Ecological Chemistry, Department of Chemistry, Technical University of Lodz, Lodz, Poland
}

\begin{abstract}
Homocysteine is an amino acid, which plays several important roles in human physiology. A wide range of disorders, including neuropsychiatric disorders and autism, are associated with increased homocysteine levels in biological fluids. Various B vitamins: B6 (pyridoxine), B12 (cobalamin), and B9 (folic acid) are required as co-factors by the enzymes involved in homocysteine metabolism. Therefore, monitoring of homocysteine levels in body fluids of autistic children can provide information on genetic and physiological diseases, improper lifestyle (including dietary habits), as well as a variety of pathological conditions. This review presents information on homocysteine metabolism, determination of homocysteine in biological fluids, and shows abnormalities in the levels of homocysteine in the body fluids of autistic children.
\end{abstract}

Key words: autism, homocysteine, vitamins, nutritions, supplementation, metabolism

Received: 18 September, 2012; revised: 07 March, 2013; accepted: 30 May, 2013; available on-line: 06 June, 2013

\section{INTRODUCTION}

Homocysteine is a non-protein, naturally occurring amino acid of potential clinical significance. It is a homologue of the amino acid cysteine (Fig. 1, Table 1).

Homocysteine was obtained in 1935 by the reduction of homocysteine with metallic sodium in ammonia ( $\mathrm{Ri}-$ gel B, duVigneaud V, JBC 1935). The relationship between different factors (genetic, physiological, lifestyle, as well as a variety of pathological conditions) and the

Table 1. Key facts about homocysteine

- It is a non-protein amino acid.

- It is a homologue of the amino acid cysteine, differing by

an additional methylene $\left(-\mathrm{CH}_{2}-\right)$ group.
Homocysteine is not obtained from the diet

- Homocysteine can be recycled into methionine or converted into cysteine with the aid of B-vitamins

- Deficiencies of vitamins: folic acid (B9), pyridoxine (B6),

or B12 (cobalamin) lead to high levels of homocysteine.

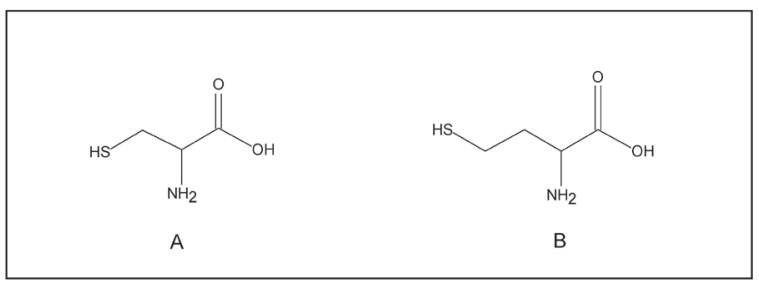

Figure 1. Structures of homocysteine and cysteine. (A) Homocysteine, (B) Cysteine level of homocysteine in plasma and urine was the subject of numerous studies. Homocystinuria, an inherited disease being the result of homozygous cystathionine- $\beta$ synthase (CBS) deficiency and characterized by episodes of thromboembolism, as well as mental retardation, hepatic steatosis, lens dislocation, and osteoporosis (Malinowska et al., 2012), was recognized as a risk factor for human diseases and described in 1960s by Carson and Niell, who found large quantities of homocysteine in the urine of siblings with mental retardation (Carson \& Niell, 1962). At the same time, during biochemical investigations of children with coșanomalies, homocystinuria was described by Gerritsen et al. (Gerritsen et al., 1962; Gerritsen \& Waisman, 1964). In 1964 Mudd et al. (1964) demonstrated that homocystinuria is caused by the deficiency or absence of cystathionine synthase. In 1969, McCully noted a link between the elevated levels of homocysteine in blood and atherosclerosis (McCully, 1969). Since the early 1990s homocysteine has become the subject of a growing number of worldwide studies and the leading theme of many international conferences. The mainstream of research examines the impact of elevated levels of homocysteine in cardiovascular (Jacobsen, 1998; Auer et al., 2001) and neural tube defects (Nelen, 2001; Hague, 2003), mental illness, and cognitive impairment (Seshadri et al., 2002; Nilsson et al., 2002). Homocysteine is a sensitive indicator of subclinical folate or vitamin B12 deficiencies, rather than a standard hematologic indicator (Duthie et al., 2002). For example, in uremic patients without other evidence of folate deficiency, folate supplementation reduced the degree of hyperhomocysteinemia, but did not consistently restore the level of homocysteine to its normal value (Thambyrajah et al., 2000; Perna et al., 2005). The connection between autism spectrum disorders (ASD) and hyperhomocysteinemia was presented for the first time by Paşca in 2006 (Paşca et al., 2006).

\section{HOMOCYSTEINE METABOLISM}

Homocysteine as a metabolic intermediate is derived from an essential sulphur containing amino acid - methionine, as a result of transformation of methionine

e-mail: joanna.kaluzna-czaplinska@p.lodz.pl

Abbreviations: $\left(-\mathrm{CH}_{2}\right)$ group, methylene group; ASD, autism spectrum disorders; B12, cobalamin; B6, pyridoxine; B9, folic acid; BHMT, betaine homocysteine methyltransferase; CBS, cystathionine $\beta$-synthase; CSF, cerebrospinal fluid; GC-MS, gas chromatographymass spectrometry; HPLC, high-performance liquid chromatography; LC-MS/MS, liquid chromatography-tandem mass spectrometry; MAT, methionine adenosyltransferase; MS, methionine synthase; MTase, methyltransferase; MTHF, methyltetrahydrofolate; MTHFR, methylenetetrahydrofolate reductase; SAH, S-adenosylhomocysteine; SAM, S-adenosylmethionine; tHcy, total homocysteine; THF, tetrahydrofolate. 
Table 2. Factors causing hyperhomocysteinemia

\begin{tabular}{|c|c|c|}
\hline Age \& sex & $\dot{\bullet}$ & $\begin{array}{l}\text { Hcy concentration increases with age } \\
\text { Hcy concentration is higher in men than in women }\end{array}$ \\
\hline Lifestyle & $\begin{array}{l}\dot{\bullet} \\
\dot{ } \\
\dot{ } \\
\dot{ }\end{array}$ & $\begin{array}{l}\text { Coffee drinking } \\
\text { Smoking } \\
\text { Alcohol consumption } \\
\text { Physical inactivity } \\
\text { Stress }\end{array}$ \\
\hline Diet & $\begin{array}{l}\dot{\bullet} \\
\dot{ } \\
\dot{ } \\
\dot{ }\end{array}$ & $\begin{array}{l}\text { Low intake of vitamins B2, B6, B12, and folic acid } \\
\text { Low intake of protein } \\
\text { High intake of methionine } \\
\text { Vegetarianism } \\
\text { Selective eating }\end{array}$ \\
\hline Drugs & $\begin{array}{l}\bullet \\
\bullet \\
\bullet\end{array}$ & $\begin{array}{l}\text { Anti-diabetic medications } \\
\text { Anti-epilepsy medications } \\
\text { Contraceptive pill }\end{array}$ \\
\hline $\begin{array}{l}\text { Enzyme } \\
\text { errors }\end{array}$ & $\dot{\bullet}$ & $\begin{array}{l}\text { Cystathionine } \beta \text {-synthase (CSB) } \\
\text { Methylenetetrahydrofolate reductase (MTHFR) }\end{array}$ \\
\hline Diseases & $\begin{array}{l}\dot{\bullet} \\
\dot{\cdot} \\
\dot{.} \\
\dot{ } \\
\dot{ }\end{array}$ & $\begin{array}{l}\text { Methionine synthase (MS) } \\
\text { Renal failure } \\
\text { Liver failure } \\
\text { Malabsorption syndrome } \\
\text { Diabetes } \\
\text { Cancer } \\
\text { Hypothyroidism } \\
\text { Lymphocytic leukemia }\end{array}$ \\
\hline
\end{tabular}

course of certain diseases such as kidney failure and cancer (Table 2).

Because of the association of the levels of plasma homocysteine with $B$ vitamins and folates intake, abnormal levels of plasma homocysteine are considered as a marker of the nutritional status. Consumption of fruit and vegetables rich in folates lowers the levels of homocysteine in plasma (Kawashima et al., 2007). Foods with naturally occurring folates are better at reducing the levels of homocysteine in blood than synthetic folic acid (Bogers et al., 2007). Synthetic folic acid has nearly double the bioavailability as folates from food. Folic acid, folinic acid (formyltetrahydrofolate), and 5-methyltetrahydrofolate constitute the major circulating forms of folates. Vitamins B12 and B6 are co-factors for enzymes involved in remethylation and transsulferation, respectively. The most preferred by clinicians form of vitamin B12 is methylcobalamin. In literature, cyanocobalamin and pyridoxine hydrochloride are the most often mentioned forms of vitamins B12 and B6 (Guilliams, 2004). One of the lifestyle factors which increases the level of homocysteine in plasma is coffee. There is no relationship between the consumption of decaffeinated coffee and plasma homocysteine levels (Grubben

(Met) to cysteine (Cys). In this conversion the following two enzymes, SAM synthetase (methionine adenosyltransferase) and S-adenosylhomocysteine (SAH)-hydrolase, take part. In the first step methionine in a reaction with ATP is activated by methionine adenosyltransferase, leading to the formation of S-adenosylmethionine (SAM) synthesis. SAM plays an important role as a major donor of methyl groups ( $-\mathrm{CH} 3)$ for various methylation reactions. In the next step, demethylation of SAM generates S-adenosylhomocysteine ( $\mathrm{SAH})$, which then undergoes a mediated hydrolysis by SAH hydrolase to adenosine and Hcy (Malinowska et al., 2012; Manolescu et al., 2010).

In the human body, homocysteine is metabolised through two B-vitamin-dependent pathways: transsulfuration to cysteine, or remethylation to methionine (Perla-Kajan et al., 2007). Homocysteine metabolism also leads to the formation of a highly reactive compound Hcy-thiolactone (HTL), the synthesis of which is connected with the misactivation of homocysteine by aminoacyl-tRNA synthetase (AARS) or erroneous activation (Jakubowski, 1990).

Homocysteine metabolism depends on the level of vitamins B6, B12, and folic acid (Brosnan et al., 2004). Deficiency of folic acid, vitamins B2, B6, B12, and errors of the following enzymes: methylenetetrahydrofolate reductase (MTHFR), cystathionine $\beta$-synthase (CBS) and methionine synthase (MS), leads to metabolic disturbances of Hcy, and elevation of Hcy in human tissues, known as hyperhomocysteinemia (Malinowska et al., 2012). Hyperhomocysteinemia may take a mild, moderate or severe form (Kang et al., 1992).

\section{THE STATUS OF THE DIETARY AND LIFESTYLE FACTORS AND THE LEVEL OF HOMOCYSTEINE IN PLASMA}

The concentration of homocysteine in body fluids depends on many factors: age, sex, diet, use of certain drugs, abuse of caffeine, alcohol, smoking, and in the et al., 2000). Coffee affects the metabolism of homocysteine in just a few hours after intake, and its effect is significant even after an overnight fast (Verhoef et al., 2002). Another lifestyle factor that influences the level of homocysteine in blood is alcohol (excluding beer) (van der Gaag et al., 2000). In case of a single instance of alcohol consumption among healthy individuals resulting in intoxication, plasma homocysteine is not increased significantly. Moderate beer consumption does not contribute to the changes in the levels of plasma homocysteine, however, there is a positive association between drinking spirits and wine and the level of homocysteine (Lutz, 2008). Another factor which affects the level of homocysteine in plasma is smoking. Among smokers, low levels of vitamins B6, B12, and folate are observed, as well as elevated levels of homocysteine in plasma (O’Callaghan et al., 2002).

\section{GENETIC ASPECT OF HOMOCYSTEINE}

The study of genetic defects associated with Hcy metabolic pathways is an important aspect of hyperhomocysteinemia. In this regard, the status of the C677T variant of the methylenetetrahydrofolate reductase (MTHFR) gene is very important. The MTHFR enzyme regulates folate availability and is responsible for the conversion of 5,10- methylenetetrahydrofolate to the 5-methyltetrahydrofolate (MTHF or 5MTHF). Codon 677 of the MTHFR gene $(677 \mathrm{C} \rightarrow \mathrm{T})$ causes a decrease in the activity of the MTHFR enzyme by $60 \%$, and an increase in the levels of plasma homocysteine levels, especially in people with low levels of B vitamins (Weisberg et al., 1998; Hustad et al., 2007). The $677 \mathrm{C} \rightarrow \mathrm{T}$ is associated with neural tube defects, cerebrovascular and cardiovascular diseases (Nakata et al., 1998; Reinhardt et al., 1998), Bjelland et al., 2003). Another important genetic aspects of hyperhomocysteinemia are cystathionine $\beta$-synthase (CBS) gene mutations. The CBS enzyme catalyzes a reas well as with psychiatric disorders (Bonig et al., 2003; 
action that permanently removes homocysteine from the methionine pathway by diverting it to the transsulfuration pathway, where vitamin B6 is needed as a co-factor. It was reported that there are associations between autism and functional gene variants within the B vitamindependent folate, methionine, and transmethylation pathways (Adams et al., 2007; Boris et al., 2007; James et al., 2006; James et al., 2010). Moreover, there are data that use of prenatal vitamins may reduce the risk of having children with autism (Schmidt et al., 2011).

Genetic alterations of enzymes such as the CBS or MTHFR have an effect on the increases of Hcy-thiolactone. Hcy-thiolactone damages proteins which may underlie the Hcy-associated cardiovascular disease in humans (Jakubowski et al., 2001; Jakubowski et al., 2009). The studies of genetic hyperhomocysteinemia in humans in animal models show that homocysteine has an important impact on atherothrombosis. Chwatko et al. (2007) presented that Hcy-thiolactone levels are elevated in hyperhomocysteinemic mice. They discovered that plasma Hcy-thiolactone is elevated 59-fold in human patients with hyperhomocysteinemia secondary to mutations in methylenetetrahydrofolate reductase and 72-fold cystathionine-synthase genes, respectively.

Ramaekers et al. (2002) presented research on children with low levels of 5-methyltetrahydrofolate in the cerebrospinal fluid. These children above the age of 4 to 6 months had neurological regression. Supplementation with folic acid eliminated the symptoms. Schmidt et al. (2011) shows a theory that children whose mothers have MTHFR 677 TT, CBS genotypes and do not report consuming prenatal vitamins have an increased risk of autism disorder.

\section{DETERMINATION OF HOMOCYSTEINE IN BIOLOGICAL FLUIDS}

Several methods are used to measure the level of homocysteine. As corrently pointed out in the work by Sawuła et al. (2008), due to the fact that a small increase in Hcy levels can constitute a risk factor for the cardiovascular disease, it is extremely important in the studies of Hcy levels to select a highly precise and accurate method. Such values are characterized by methods based on chromatography.

Among the remaining separation methods, chromatographic techniques are the most useful and often applied: ion-exchange chromatography equipped with an amino acid analyzer, high-performance liquid chromatography (HPLC) with electrochemical, fluorescent, or UV detection (House et al., 2000; Shoveller et al., 2004; Sawuła et al., 2008; Sawuła et al., 2009), liquid chromatography-tandem mass spectrometry (LC-MS/MS) (Rafii et al., 2007), capillary electrophoresis (Caussé et al., 1999) and gas chromatography-mass spectrometry (GC-MS) (Kałużna-Czaplińska et al., 2011a). All these methods have their advantages and limitations related to sensitivity, selectivity, samples derivatization, analysis reproducibility, measurement and equipment costs etc. The choice of the method depends mainly on its availability and the particular need in analysis.

\section{VITAMIN DEFICIENCY, SUPPLEMENTATION, AND AUTISM}

In recent years, abnormalities in the levels of amino acids in the human body have been identified in children with different disorders and autism (Bongiovanni
\& Feinerman, 2003; James et al., 2004). Amino acids, including homocysteine, are expelled in urine and plasma, and provide essential information on the diet and functioning of the alimentary system. Several studies on the neurotoxicity of homocysteine indicate that Hcy can induce neuronal damage and cell loss through excitotoxicity as well as apoptosis (Sawada et al., 1982; Lee et al., 1988; Lipton et al., 1997; Kruman et al., 2000). One of the reasons for this state may be the failure of cerebral tissue to metabolize Hcy by the betaine and transsulfuration pathways, resulting in the accumulation of Hcy in the nervous system (Finkelstein, 1998).

Many studies have reported the beneficial effects of vitamin and nutritional supplements in the treatment of autism spectrum and other neurological disorders. Monitoring of homocysteine levels in various body fluids gives information about possible deficiencies of various B vitamins: B6, B12, and folic acid (Nekrassova et al., 2003). Refsum et al. (2004) discussed the application of total homocysteine (tHcy) measurements in the diagnosis of folate and vitamin B12 deficiencies in various psychiatric and neurologic disorders. High levels of homocysteine and oxidative stress are generally associated with neuropsychiatric disorders such as autism (Chauhan \& Chauhan, 2006; Suh et al., 2008). Homocysteine is a powerful excitotoxin, and its metabolism products cause protein damage and structural changes which generate toxic proteins and induce an autoimmune response (Jakubowski \& Głowacki, 2011).

Table 3 shows the comparison of the level of homocysteine, folate and vitamin B12 in biological fluids between autistic children and control children.

Pasca et al. (2006) were the first who discovered the relationship between the levels of homocysteine in serum of autistic children and vitamin B12 deficiency. They found out that high levels of homocysteine and oxidative stress markers are associated with autism. Their studies showed statistically significant differences in tHcy levels and arylesterase activities of human paraoxonase 1 (PON1) in children with autism compared to the control group. Kałużna-Czaplińska et al., (2009) identified potential nutritional deficits in children with autism, and the relationship between the diet and functioning of an autistic child. The analysis of daily intake of nutrients by autistic children based on a 7-day diet and their parents' reports shows that autistic children have deficiencies of vitamins B6, B9, B12, and C caused by improper diets. The characteristics of the functioning of autistic children based on psychological tests and speech therapy were also analyzed. The studies showed that the diet of autistic children should be enriched in vitamins of group B and vitamin C. Such an approach was rationalized by systematic studies based on the analysis of homocysteine in the urine of autistic children performed by GC-MS method (Kałużna-Czaplińska et al., 2011a). The levels of homocysteine in urine samples of autistic children were significantly higher than those of healthy children. The results were very helpful in preparing and determining individual diets for autistic children. It appeared that vitamin supplementation reduces the levels of homocysteine in the urine of autistic children (Kałużna-Czaplińska et al., 2011b). Moreover, the results showed that a dietary intake of vitamins B6, B12, and folic acid is more effective than the intake of vitamin B6 and B12 alone. The results lead to the recommendation of supplementing the diets of autistic children with vitamins B6, B12, and folic acid. Similar conclusions come from the paper of Ali et al. (2011). Supplementary intake of vitamins B6, $\mathrm{B} 12$, and folate was effective in lowering the levels of 
Table 3. The comparison of the level of Hcy, folate and vitamin B12 in biological fluids between autistic children and the control group

\begin{tabular}{|c|c|c|c|c|c|}
\hline Metabolite & Material & Autistic children & Control group & $\begin{array}{l}\text { Statistically } \\
\text { significant }\end{array}$ & Literature \\
\hline Folate $(\mathrm{ng} / \mathrm{mL})$ & serum & $12.1 \pm 9.2$ & $7.5 \pm 5.5$ & - & (Lowe et al., 1981) \\
\hline Folate (ng/mL) & red blood cell & $304.9 \pm 216.5$ & $284.5 \pm 169.9$ & - & \\
\hline Vitamin B12 (pg/mL) & serum & $571.8 \pm 166.1$ & $537.5 \pm 197.8$ & - & \\
\hline Hcy ( $\mu \mathrm{mol} / \mathrm{L})$ & plasma & $5.8 \pm 1.0$ & $6.4 \pm 1.3$ & $\mathrm{p}<0.01$ & (James et al., 2004) \\
\hline Hcy ( $\mu \mathrm{mol} / \mathrm{L})$ & plasma & $9.83 \pm 2.75$ & $7.51 \pm 0.93$ & $p \leq 0.01$ & (Pasca et al., 2006) \\
\hline Vitamin B12 (pmol/mL) & plasma & $368.16 \pm 154.64$ & - & - & \\
\hline Hcy (mmoL/moL creatinine) & urine & $2.36 \pm 1.24$ & $0.76 \pm 0.31$ & $p<0.05$ & (Kałużna-Czaplińska et al., \\
\hline Hcy (mmoL/moL creatinine) & urine & $2.41 \pm 1.10$ & $0.76 \pm 0.31$ & $\mathrm{p}<0.05$ & 2011a) \\
\hline Hcy (mmoL/moL creatinine)* & urine & $1.13 \pm 0.44$ & - & - & (Kałużna-Czaplińska et al., \\
\hline Hcy (mmoL/moL creatinine)** & urine & $1.33 \pm 0.39$ & - & - & 2011b) \\
\hline Hcy $(\mu \mathrm{mol} / \mathrm{L})$ & serum & $20.1 \pm 3.3$ & $9.64 \pm 2.1$ & $p<0.05$ & (Ali et al., 2011) \\
\hline Folate $(\mu \mathrm{g} / \mathrm{L})$ & serum & $1.8 \pm 0.4$ & $6.1 \pm 0.6$ & $\mathrm{p}<0.05$ & \\
\hline Vitamin B12 (pg/mL) & serum & $191.1 \pm 0.9$ & $288.9 \pm 1.3$ & $p<0.05$ & \\
\hline
\end{tabular}

*autistic children after a 3-month treatment: folic acid, vitamins B6 and B12; **autistic children after a 3-month treatment: vitamins B6 and B12.

blood homocysetine. Previous studies from 1981 (Lowe et al. 1981) showed that the level of $B$ vitamins in biological fluids of autistic children and the levels of serum folate and vitamin B12 are congruous in autistic children and the control group. These findings may result from the fact that more than half of the autistic children were treated with daily vitamin supplements containing $\mathrm{B}$ vitamins. James et al. (2004) investigated the abnormal metabolism of methionine and homocysteine and also presented the congruous level of Hcy in the plasma of autistic children in comparison with the control group. The decreased capacity for methylation associated with low levels of plasma homocysteine in children with autism was related to the fact that $80 \%$ of autistic children were taking folic acid and vitamin B12 supplements prior to the beginning of the study. Such a treatment decreased the level of homocysteine and resulted in almost the same level of homocysteine in the plasma of autistic children and the control group.

The fact is that nutritional supplements like $\mathrm{B}$ vitamins should not be the primary source of nutrition but sometimes it is difficult to get enough B vitamins from food. Waśkiewicz et al. (2007) presented the results of an inadequate intake of vitamins B6, B12, and folate in Polish population. 49 to $84 \%$ of the population includes the recommended amounts of vitamins B6, B12, and folic acid in their daily diet, while the recommended daily quantity of folic acid is taken only by $10 \%$ of women and $22 \%$ of men. Also, it is very difficult to maintain an adequate intake of $\mathrm{B}$ vitamins with a balanced diet for some groups like vegetarians, and it is a big problem in countries with no fortification of foods with $B$ vitamins. It is especially difficult to get all the necessary B vitamins from food; therefore supplements are essential (Finglas et al., 2006).

According to the studies conducted by Xia et al. (2010), dietary habits of autistic children shows that most of them had inadequate intake of folic acid, vitamins B6, A, C, and zinc. Dietary deficiency of vitamin B12 was identified as the cause of partially reversible optic neuropathy in 3 autistic children (Pineles et al., 2010). Treatment with vitamin B12 and normalization of vita- min B12 levels resulted in the improvement of visual functioning of children. These investigations show that food selectivity and vitamin deficiency cause visual loss and optic atrophy. According to another report (Paul et al., 2007), in the case of some autistic children vitamin deficiencies are caused by improper dietary habits and increased food selectivity. Deficiencies in folic acid as well as vitamins B6 and B12 in the nutrition result in higher levels of homocysteine and an increase in some autistic symptoms (Williams et al., 2005). The theory of efficacies of nutritional supplements of vitamin B6 in autism-spectrum disorders was presented by Adams et al. (2004). His paper shows statistically significant improvements in sleep and gastrointestinal problems in autistic children compared to the placebo group. Also, $\mathrm{Xia}$ (2011) described a case of a 9-year-old boy with autism who responded positively to vitamin B6 nutritional supplements. This diet resulted in the improvement of communication, sociability, cognitive awareness, and behavior.

The studies suggest a very important relationship between high levels of homocysteine and deficiencies of vitamins B: B6, B12, and folic acid for the proper functioning of autistic children. The higher level of homocysteine in the body fluids can be used as a marker of possible nutritional deficits of $B$ vitamins.

\section{CONCLUSIONS}

The high level of serum and urinary homocysteine is associated with pathophysiology of autism spectrum disorders and may serve as a diagnostic tool for the detection of nutrient deficiencies in the case of autistic children. However, it should be very carefully considered whether abnormal levels of homocysteine are the result of nutritional deficiencies in children or they result from genetic and physiological diseases or other pathological conditions.

A recent report has revealed that folate or methionine metabolism is altered in autistic children. The cycle of folate-methionine can play a key role in the etiology of autism. 
There is a need to confirm whether the supplementation of the deficits in folate and vitamins B6 and B12 in the metabolism of autistic children leads to behavioral and functional benefits.

\section{REFERENCE}

Adams JB, Holloway C (2004) Pilot study of a moderate dose multivitamin/mineral supplement for children with autistic spectrum disorder. J Altern Complement Med 10: 1033-1039.

Adams M, Lucock M, Stuart J, Fardell S, Baker K, Ng X (2007) Preliminary evidence for involvement of folate gene polymorphism 19bp deletion-DHFR in occurrence of autism. Neurosci Lett 422: 24-29.

Ali A, Waly MI, Al-Farsi YM, Essa MM, Al-Sharbati MM, Deth RC (2011) Hyperhomocysteinemia among Omani autistic children: a case-control study. Acta Biochim Pol 58: 547-551.

Auer J, Berent R, Eber B (2001) Homocysteine and risk of cardiovascular disease. J Clin Basic Cardiol 4: 261-264.

Bald E, Kaniowska E, Chwatko G, Glowacki R (2000) Liquid chromatographic assessment of total and protein-bound homocysteine in human plasma. Talanta 50: 1233-1243.

Bjelland I, Tell GS, Vollset SE, Refsum H, Ueland PM (2003) Folate, vitamin B12, homocysteine, and the MTHFR 677CT polymorphism in anxiety and depression: the Hordaland Homocysteine Study. Arch Gen Psychiatry 60: 618-626.

Bogers RP, Dagnelie PC, Bast A, van Leeuwen M, van Klaveren JD, van den Brandt PA (2007) Effect of increased vegetable and fruit consumption on plasma folate and homocysteine concentrations. Nutrition 23: 97-102.

Bongiovanni B, Feinerman J (2003) Amino Acid Profiling: clinical guidelines for determination of preferred specimen choice. Townsend Letter for Doctors and Patients 245: 38-42.

Bonig H, Daublin G, Schwahn B, Wendel U (2003) Psychotic symptoms in severe MTHFR deficiency and their successful treatment with betaine. Eur I Pediatr 162: 200-201.

Boris M, Goldblatt A, Galanko J, James SJ (2004) Association of MTHFR gene variants with autism. J Am Phys Surg 9: 106-108.

Brosnan JT, Jacobs RL, Stead LM, Brosnan ME (2004) Methylation demand: a key determinant of homocysteine metabolism. Acta Biochim Pol 51: 405-413.

Riegel B, Du Vigneaud V (1935) The isolation of homocysteine and its conversion to a thiolactone. I Biol Chem 112: 149-154.

Shih DM, Gu L, Navab M, Li WF, Hama S, Castellani Carson NA, Neill DW (1962) Metabolic abnormalities detected in a survey of mentally backward individuals in Northern Ireland. Arch Dis Child 37: 505-513.

Caussé E, Siri N, Bellet H, Champagne S, Bayle C, Valdiguié P, Salvayre R, Couderc F (1999) Plasma homocysteine determined by capillary electrophoresis with laser-induced fluorescence detection. Clin Chem 45: 412-414.

Chauhan A, Chauhan V (2006) Oxidative stress in autism. Pathophysiology 13: 171-181.

Chwatko G, Boers GHJ, Strauss KA, Shih DM, Jakubowski H (2007) Mutations in methylenetetrahydrofolate reductase or cystathionine beta-syntase gene, or a high-methionine diet, increase homocysteine thiolactone levels in humans and mice. FASEB J 21: 1707-1713.

Duthie SJ, Whalley LJ, Collins AR, Leaper S, Berger K, Deary IJ (2002) Homocysteine, B vitamin status, and cognitive function in the elderly. Am J Clin Nutr 75: 908-913.

Esmon CT, Owen WG (1981) Identification of an endothelial cell cofactor for thrombin-catalyzed activation of pro-tein C. Proc Natl Acad Sci USA 78: 2249-2252.

Finglas PM, de Meer K, Molloy A, Verhoef P, Pietrzik K, Powers HJ, van der Straeten D, Jägerstad M, Varela-Moreiras G, van Vliet T, Havenaar R, Buttriss J, Wright AJ (2006) Research goals for folate and related B vitamin in Europe. Eur I Clin Nutr 60: 287-294.

Finkelstein JD (1998) The metabolism of homocysteine: pathways and regulation. Eur J Pediatr 157: S40-S44.

van der Gaag MS, Ubbink JB, Sillanaukee P, Nikkari S, Hendriks HF (2000) Effect of consumption of red wine, spirits, and beer on serum homocysteine. Lancet 355: 1522. Gerritsen T, Vaughn JG, Waisman HA (1962) The identification of homocystine in the urine. Biochem Biophys Res Commun 9: 493-496.

Gerritsen T, Waisman HA (1964) Homocystinuria, an error in the metabolism of methionine. Pediatrics 33: 413-420.

Grubben MJ, Boers GH, Blom HJ, Broekhuizen R, de Jong R, van Rijt L, de Ruijter E, Swinkels DW, Nagengast FM, Katan MB (2000) Unfiltered coffee increases plasma homocysteine concentrations in healthy volunteers: a randomized trial 1-3. Am J Clin Nutr 71: $480-484$.

Guilliams TG (2004) Homocysteine: a risk factor worth treating. The Standard 6: 1-8.
Hague WM (2003) Homocysteine and pregnancy. Best Pract Res Clin Obstet Gynaecol 17: 459-446.

House JD, March SB, Ratnam S, Ives E, Brosnan JT, Friel JK (2000) Folate and vitamin B12 status of women in Newfoundland at their first prenatal visit. CMAJ 162: 1557-1559.

Jacobsen DW (1998) Homocysteine and vitamins in cardiovascular disease. Clin Chem 44: 1833-1843.

Hustad S, Midttun O, Schneede J, Vollset SE, Grotmol T, Ueland PM (2007) The methylenetetrahydrofolate reductase $677 \mathrm{C} \rightarrow \mathrm{T}$ polymorphism as a modulator of a $\mathrm{B}$ vitamin network with major effects on homocysteine metabolism. Am J Hum Genet 80: 846-555.

Jakubowski H (1990) Proofreading in vivo: editing of homocysteine by methionyl-tRNA synthetase in Escherichia coli. Proc Natl Acad Sci USA 87: 4504-4508.

Jakubowski H, Ambrosius WT, Pratt JH (2001) Genetic determinants of homocysteine thiolactonase activity in humans: implications for atherosclerosis. FEBS Lett 491: 35-39.

Jakubowski H, Perla-Kaján J, Finnell RH, Cabrera RM, Wang H, Gupta S, Kruger WD, Kraus JP, Shih DM (2009) Genetic or nutritional disorders in homocysteine or folate metabolism increase protein Nhomocysteinylation in mice. FASEB J 23: 1721-1727.

Jakubowski H, Głowacki R (2011) Chemical biology of homocysteine thiolactone and related metabolites. Adv Clin Chem 55: 81-103.

James SJ, Cutler P, Melnyk S, Jernigan S, Janak L, Gaylor DW, Neubrander JA (2004) Metabolic biomarkers of increased oxidative stress and impaired methylation capacity in children with autism. Am J Clin Nutr 80: 1611-1617.

James SJ, Melnyk S, Jernigan S, Cleves MA, Halsted CH, Wong DH, Cutler P, Bock K, Boris M, Bradstreet JJ, Baker SM, Gaylor DW (2006) Metabolic endophenotype and related genotypes are associated with oxidative stress in children with autism. Am J Med Genet B Neuropsychiatr Genet 141: 947-956.

James SJ, Melnyk S, Jernigan S, Pavliv O, Trusty T, Lehman S, Seidel L, Gaylor DW, Cleves MA (2010) A functional polymorphism in the reduced folate carrier gene and DANN hypomethylation in mothers of children with autism. Am J Med Genet B Neuropsychiatr Genet 153B: 1209-1220.

Kałużna-Czaplińska J, Michalska M, Rynkowski J (2011a) Homocysteine level in urine of autistic and healthy children. Acta Biochim Pol 58: 31-34.

Kałużna-Czaplińska J, Michalska M, Rynkowski J (2011b) Vitamin supplementation reduces the levels of homocysteine in the urine of autistic children. Nutr Res 31: 318-321.

Kałużna-Czaplińska J, Michalska M, Socha E, Błaszczyk S, RozettiSzymańska A, Rynkowski J (2009) Nutritional deficiencies in children for example of autistic children. Nowa Pediatria 4: 94-100 (in Polish).

Kang SS, Wong PW, Malinow MR (1992) Hyperhomocysteinemia as a risk factor for occlusive vascular disease. Ann Rev Nutr 12: 278-298.

Kawashima A, Madarame T, Koike H, Komatsu Y, Wise JA (2007) Four week supplementation with mixed fruit and vegetable juice concentrates increased protective serum antioxidants and folate and decreased plasma homocysteine in Japanese subjects. Asia Pac J Clin Nutr 16: 411-421.

Kruman I. I., Culmsee C., Chan S. L., Kruman Y., Guo Z., Penix L. and Mattson MP (2000) Homocysteine elicits a DNA damage response in neurons that promotes apoptosis and hypersensitivity to excitotoxicity. J Neurosic 20: 6920-6926.

Lee M, Strahlendorf HK, Strahlendorf JC (1988) Differential effects of $\mathrm{N}$-methyl d-aspartic acid and l-homocysteic acid on cerebellar Purkinje neurons. Brain Res 456: 104-112.

Lowe TL, Cohen DJ, Miller S, Young JG (1981) Folic acid and B12 in autism and neuropsychiatric disturbances of childhood. I Am Acad Child Psychiatry 20: 104-111.

Lipton SA, Kim WK, Choi YB, Kumar S, D’Emilia DM, Rayudu PV, Arnelle DR, Stamler JS (1997) Neurotoxicity associated with dual actions of homocysteine at the N-methyl-D-aspartate receptor. Proc Natl Acad Sci 94: 5923-5928.

Lutz UC (2008) Alterations in homocysteine metabolism among alcohol dependent patients - clinical, pathobiochemical and genetic aspects. Curr Drug Abuse Rev 1: 47-55.

Malinowska J, Kolodziejczyk J, Olas B (2012) The disturbance of hemostasis induced by hyperhomocysteinemia; the role of antioxidants. Acta Biochim Pol 59: 185-194.

McCully KS (1969) Vascular pathology of homocysteinemia: implications for the pathogenesis of arteriosclerosis. Am I Pathol 56: 111128.

Manolescu BN, Oprea E, Farcasanu IC, Berteanu M, Cercasov C (2010) Homocysteine and vitamin therapy in stroke prevention and treatment: a review. Acta Biochim Pol 57: 467-477.

Mudd SH, Finkelstein JD, Irreverre F, Laster L (1964) Homocystinuria: An enzymatic defect. Science 143: 1443-1445.

Nakata Y, Katsuya T, Takami S, Sato N, Fu Y, Ishikawa K, Takiuchi S, Rakugi H, Miki T, Higaki J, Ogihara T (1998) Methylenetetrahydrofolate reductase gene polymorphism: relation to blood pressure and cerebrovascular disease. AmJ Hypertens 11: 1019-1023. 
Nekrassova O, Lawrence NS, Compton RG (2003) Analytical determination of homocysteine: a review. Talanta 60: 1085-1095.

Nelen WL (2001) Hyperhomocysteinaemia and human reproduction. Clin Chem Lab Med 39: 758-763.

Nilsson K, Gustafson L, Hultberg B (2002) Relationship between plasma homocysteine and Alzheimer's disease. Dement Geriatr Cogn Disord 14: 7-12.

O'Callaghan P, Meleady R, Fitzgerald T, Graham I, the European COMAC Group (2002) Smoking and plasma homocysteine. Eur Heart J 23: 1580-1586.

Paşca SP, Nemes B, Vlase L, Gagyi CE, Dronca E, Miu AC, Dronca M (2006) High levels of homocysteine and low serumparaoxonase 1 arylesterase activity in children with autism. Life Sci 78: 2244-2248.

Paul C, Williams KE, Riegel K, Gibbons B (2007) Combining repeated taste exposure and escape prevention: an intervention for the treatment of extreme food selectivity. Appetite 49: 708-711.

Perła-Kajan J, Twardowski T, Jakubowski H (2007) Mechanisms of homocysteine toxicity in humans. Amino Acids 32: 561-572.

Perna AF, Capasso R, Lombardi C, Acanfora F, Satta E, Ingrosso D (2005) Hyperhomocysteinemia and macromolecule modifications in uremic patients. Clin Chem Lab Med 43: 1032-1038.

Pineles SL, Avery RA, Liu GT (2010) Vitamin B12 optic neuropathy in autism. Pediatrics 126: 967-970.

Rafii M, Elango R, Courtney-Martin G, House JD, Fisher L, Pencharz PB (2007) High-throughput and simultaneous measurement of homocysteine and cysteine in human plasma and urine by liquid chromatography-electrospray tandem mass spectrometry. Anal Biochem 371: $71-81$.

Ramaekers VT, Hausler M, Opladen T Heimann G, Blau N (2002) Psychomotor retardation, spastic paraplegia, cerebellar ataxia, and dyskinesia associated with low 5-methyltetrahydrofolate in cerebrospinal fluid: a novel neurometabolic condition responding to folinic acid substitution. Neuropediatrics 33: 301-308.

Refsum H, Smith AD, Ueland PM, Nexo E, Clarke R, McPartlin J, Johnston C, Engbaek F, Schneede J, McPartlin C, Scott JM (2004) Facts and recommendations about total homocysteine determinations: an expert opinion. Clin Chem 50: 3-32.

Reinhardt D, Sigusch HH, Vogt SF, Farker K, Müller S, Hoffmann A (1998) Absence of association between a common mutation in the methylenetetrahydrofolate reductase gene and the risk of coronary artery disease. Eur J Clin Invest 28: 20-23.

Sawada S, Takada S, Yamamoto C (1982) Excitatory actions of homocysteic acid on hippocampal neurons. Brain Res 238: 282-285.

Sawuła W, Banecka-Majkutewicz Z, Kadziński L, Jakóbkiewicz-Banecka J, Wegrzyn G, Nyka W, Banecki B (2008) Improved HPLC method for total plasma homocysteine detection and quantification. Acta Biochim Pol 55: 119-125.

Sawuła W, Banecka-Majkutewicz Z, Kadziński L, Jakóbkiewicz-Banecka J, Wegrzyn G, Nyka W, Banecki B (2009) Homocysteine level and metabolism in ischemic stroke in the population of Northern Poland. Clin Biochem 42: 442-447.

Schmidt RJ, Hansen RL, Hartiala J, Allayee H, Schmidt LC, Tancredi DJ, Tassone F, Hertz-Picciotto I (2011) Prenatal vitamins, one-carbon metabolism gene variants, and risk for autism. Epidemiology 224: 476-485.

Seshadri S, Beiser A, Selhub J, Jacques PF, Rosenberg IH, D’Agostino RB, Wilson PW, Wolf PA (2002) Plasma homocysteine as a risk factor for dementia and Alzheimer's disease. N Engl J Med 346: 476-483.

Shoveller AK, House JD, Brunton JA, Pencharz PB, Ball RO (2004) The balance of dietary sulfur amino acids and the route of feeding affect plasma homocysteine concentrations in neonatal piglets. J Nutr 134: 609-612.

Suh JH, Walsh WJ, McGinnis WR, Lewis A, Ames BN (2008) Altered sulfur amino acid metabolism in immune cells of children diagnosed with autism. Am J Biochem Biotec 4: 105-113.

Thambyrajah J, Landray MJ, McGlynn FJ, Jones HJ, Wheeler DC, Townend JN (2000) Does folic acid decrease plasma homocysteine and improve endothelial function in patients with predialysis renal failure? Circulation 102: 871-875.

Verhoef P, Pasman WJ, Van Vliet T, Urgert R, Katan MB (2002) Contribution of caffeine to the homocysteine-raising effect of coffee: a randomized controlled trial in humans. Am J Clin Nutr 76: 1244-1248.

Waśkiewicz A, Sygnowska E, Broda G (2010) Dietary intake of vitamins B6, B12 and folate in relation to homocysteine serum concentration in the adult Polish population - WOBASZ Project. Kardiol Pol 68: 275-282 (in Polish).

Weisberg I, Tran P, Christensen B, Sibani S, Rozen R (1998) A second genetic polymorphism in methylenetetrahydrofolate reductase (MTHFR) associated with decreased enzyme activity. Mol Genet Metab 64: 169-172.

Williams KE, Gibbons BG, Schreck KA (2005) Comparing selective eaters with and without developmental disabilities. J Dev Phys Disabil 17: 299-309.

Xia RR (2011) Effectiveness of nutritional supplements for reducing symptoms in autism- spectrum disorder: a case report. $J$ Altern Complement Med 17: 271-274.

Xia W, Zhou Y, Sun C, Wang J, Wu L (2010) A preliminary study on nutritional status and intake in Chinese children with autism. Eur J Pediatr 169: 1201-1206.

Zinellu A, Sotgia S, Usai MF, Zinellu E, Posadino AM, Gaspa L, Chessa R, Pinna A, Carta F, Deiana L, Carru C (2007) Plasma methionine determination by capillary electrophoresis-UV assay: application on patients affected by retinal venous occlusive disease. Anal Biochem 363: 91-96. 